\title{
Ammonium Polyphosphate and Ammonium Orthophosphate as Sources of Phosphorus for Jerusalem artichoke
}

\author{
Said Abbas Mohammed EL-Sayed ${ }^{1}$
}

\begin{abstract}
A field experiment was initiated in 2010 to compare the effects of liquid ammonium polyphosphate (APP) and granular diammonium phosphate (DAP) on growth, nutrient content, and yield of Jerusalem artichoke (Helianthus tuberosus L.). Two sites on a coarse-textured Inceptisol with markedly different cropping histories were selected, one with $6 \mathrm{ppm} P$, the other with $>201 \mathrm{ppm} \mathrm{P}$ extractable with $0.05 \mathrm{~N} \mathrm{HCl}+0.025 \mathrm{~N} \quad \mathrm{H}_{2} \mathrm{SO}_{4}$.Fertilizers were banded at $P$ rates of $0,24,48$, and $71 \mathrm{~kg} / \mathrm{Fed}$. at the low $P$ site, and 0,10 , and $20 \mathrm{~kg} / \mathrm{Fed}$. at the high $P$ site. At the low $P$ site tuber yields and tissue $P$ concentrations were lower in case of (APP) than that of (DAP), while tissue concentrations of $\mathrm{Ca}, \mathrm{Mg}, \mathrm{Mn}$, and $\mathrm{Zn}$ were higher in case of (APP). At the high $P$ site, tuber yield and top dry weight were not affected by $P$ source, but tissue $C a$ and $M g$ contents were higher and tissue $P$ was lower with (APP). In 2011 and 2012, (DAP) and(APP) were applied at a rate of $24 \mathrm{~kg} P / F e d$. at the low $P$ site. Tissue levels of $P$ again were lower while these of $\mathrm{Ca}, \mathrm{Mg}, \mathrm{Mn}$, and $\mathrm{Zn}$ were higher with (APP) for the two years. Tuber yields were lower with (APP) in 2012.
\end{abstract}

In 2010, (DAP) and(APP) were applied at the high $P$ site at the same rates used in 2010. Yields were unaffected by $P$ source but tissue $P$ content was lower but tissue $Z n$ content was higher in case of (APP). Extractable P levels in soil samples taken after harvest were higher in 2010 for (APP) treatment .With time, extractable $P$ declined for both sources, and by the following crop season, there were no differences in extractable $P$ between $P$ source. Extractable $P$ again was higher in 2012 where (APP) had been applied. The results showed that availability of $P$ fertilizer for summer planted Jerusalem artichoke was less with(APP) than that of (DAP). Less P was found in tops of Jerusalem artichoke with (APP) regardless of the level of available soil $P$. Tuber yields, however, were less affected by $P$ source, and the data suggest that most years tuber yields will not be different with these two sources except on soil with very low levels of available $P$. Application of (APP) also resulted in increased uptake of $\mathrm{Ca}, \mathrm{Mg}, \mathrm{Mn}$, and $\mathrm{Zn}$ by Jerusalem artichoke.

Key Words:Jerusalem artichoke, Ammonium orthophosphate (AOP), Ammonium polyphosphate (APP), Diammonium phosphate (DAP), Top try weight(TDW).

\section{INTRODUCTION}

The value of polyphosphate fertilizer as a source of phosphorus (P) for plants after application appears to be largely dependent on its rate of hydrolysis to orthophosphate (OP). Although several factors affect the hydrolysis rate (Van Wazer, 1958), Sutton and Larsen (1964) found that the most important factor in soils was the level of biological activity. In soils with low levels of biological activity, $\mathrm{P}$ uptake by ryegrass (Lolium Multiflorum) was significantly lower with pyrophosphate (PP) than with (OP). Differences between $\mathrm{P}$ sources in soils with higher levels of biological activity were detectable only in the first cutting. Uptake of $\mathrm{P}$ by barley (Hordeum vulgare L.) from solutions containing ( PP) was lower by a factor of 2.4 than from (OP) solutions. Results of Hughes and Hashimoto (1971) also support the finding that (OP) is more readily absorbed by plants than is (PP). Sutton et al. (1966) compared the uptake of $P$ from both (OP) and (PP) over a wide range of field conditions and attempted to quantify the level of biological activity required for efficient hydrolysis of (PP). They found that P uptake was lower from PP at 59 of 98 sites, suggesting that restricted hydrolysis was common in these soils. The extent of hydrolysis for a given soil was found to be directly proportional to both $\mathrm{CO}_{2}$ production and temperature. In addition to the rate of hydrolysis, they stated that time of maximum P uptake by the crop and $P$ status of the soil would both affect the efficiency of (PP) in crop production.

In a short-term pot experiment, Engelstad and Allen (1971) found that (PP) was less effective than( OP) for corn (Zea mays L.) in cool soil. In warm soil, no differences between the two sources were observed. Incubation of the fertilized soil under cool condition prior to seeding did not alter the results. However, (PP) was more effective than (OP) when incubated under warm conditions, but effectiveness of both sources was decreased. They concluded that early growth and $\mathrm{P}$ uptake from fertilizer composed primarily of condensed phosphates such as (PP) may not be equal to that from (OP) when crops are grown in cool soils.

Jerusalem artichoke (Helianthus tuberosus L.) production is very important in Egypt. This study was initiated to compare polyphosphate with (OP) as $\mathrm{P}$ sources for this crop. Jerusalem artichokes are planted in summer. Recommended cultural practices include soil fumigation just prior to planting for control of soilborne pathogens. High temperatures in the season

\footnotetext{
${ }^{1}$ Soil and Water Sci. Dept., Faculty of Agriculture in Assiut, Al-Azhar University

Received January 26, 2015, Accepted March15, 2015
} 
along with soil sterilization resulting from fumigation could reduce biological activity sufficiently in these soils that the rate of hydrolysis of condensed phosphates would be a factor. The objective of this study was to compare diammonium phosphate (DAP) and ammonium polyphosphate (APP) as sources of $\mathrm{P}$ for summer-planted Jerusalem artichoke on soil with a wide range of available $P$.

\section{MATERIALS AND METHODS}

This study was conducted on a placid sand (Typic Humaquept, Sancty Siliceaus, hyperthermic) \{Soil Survey Staff (1998) and U. S. D. A. (2011)\} located at Nubaria Agric. Res. Station at Alexandria. Two near by sities were selected: a virgin site, referred to here after at the low $\mathrm{P}$ site, which had never received $\mathrm{P}$ fertilizer, and a site that had been in continuous Jerusalem artichoke production for about 10 years, refered to here as the high $\mathrm{P}$ site. Chemical properties of the soil from two sites are given in Table (1).

\section{The year of 2010}

The experimental design at both sites was a split plot with lime as main plots and $\mathrm{P}$ sources and rates as subplots in a completely randomized, block design with three replications. Dolomitic lime at rates of $0,0.84$, $1.68,3.36,100.8,201.6$ and $403.2 \mathrm{~kg} / \mathrm{fed}$. at the low $\mathrm{P}$ site . But, rate of $0,1.26,2.52,58.38$, and $116.76 \mathrm{~kg} / \mathrm{fed}$. at the high $\mathrm{P}$ site were applied broadcast and decided into the soil on 10 April 2009. Application of the highest rates of lime resulted in $\mathrm{P}^{\mathrm{H}}$ levels between 6.5 and 7.0 at both sites. Seed pieces of Fusea Jerusalem artichoke were planted at each site on 10 March $20-\mathrm{cm}$ apart. All subplots consisted of 8 rows which were 8.5 $\mathrm{m}$ in length and spaced approximately 1-m apart.

Phosphorus treatments consisted of granular (DAP) (18-20-0) and liquid (APP) (10-15-0). The (APP) contained $75 \%$ of its $\mathrm{P}$ in condensed forms. Each sources of $\mathrm{P}$ was applied at rates of $0,24,48$, and $71 \mathrm{~kg}$ $\mathrm{P} /$ fed. at the low $\mathrm{P}$ site and 0,10 , and $20 \mathrm{~kg} \mathrm{P} /$ fed. at the high $\mathrm{P}$ site. Nitrogen and Potassium rates at planting were 63.4 and $71 \mathrm{~kg} / \mathrm{fed}$. Respectively, with $\mathrm{K}$ as $\mathrm{K}_{2} \mathrm{SO}_{4}$ and any $\mathrm{N}$ in excess of that in the $\mathrm{P}$ material at $\mathrm{NH}_{4} \mathrm{NO}_{3}$. A fritted micronutrient source was applied at planting which gave the following rates of micronutrients (in $\mathrm{kg} / \mathrm{fed}$.): $\mathrm{Cu}, 0.714 ; \mathrm{Zn}, 1.64 ; \mathrm{Mn}$, 1.76; Fe, 4.24; Mo, 0.042; and B, 0.714. All of the dry fertilizer materials were mixed together and then applied at planting in two bands $20-\mathrm{cm}$ apart on each

Table 1. Some initial chemical characteristics of the placid Sand located at Nubaria Agric. Res. Satation at Alexandria

\begin{tabular}{ccccccccc}
\hline site & $\mathbf{P}^{\mathrm{H}}$ & $\begin{array}{c}\mathbf{C a} \\
(\mathbf{p p m})\end{array}$ & $\begin{array}{c}\mathbf{M g} \\
\mathbf{( p p m )}\end{array}$ & $\mathbf{P}(\mathbf{p p m})$ & $\mathbf{k}(\mathbf{p p m})$ & $\begin{array}{c}\mathbf{M n} \\
(\mathbf{p p m})\end{array}$ & $\begin{array}{c}\text { Zn } \\
(\mathbf{p p m})\end{array}$ & $\begin{array}{c}\text { Organic matter } \\
\mathbf{\%}\end{array}$ \\
\hline Low P & 5.2 & 121 & 24 & 6 & 23 & 1.1 & 1.3 & 2.7 \\
\hline High P & 5.4 & 501 & 23 & 238 & 57 & 3.6 & 6.5 & 1.5 \\
\hline
\end{tabular}

side of the seed piece and at about the same depth. Liquid (10-15-0) was applied in a separate operation in two bands in contract with the dry materials. Side dress applications of $23.52 \mathrm{Kg} \mathrm{N} / \mathrm{Fed}$. and $19.32 \mathrm{Kg} \mathrm{K} / \mathrm{Fed}$. were made 35 days after planting. The sources of $\mathrm{N}$ and $\mathrm{K}$ at side dressing were $\mathrm{NH}_{4} \mathrm{No}_{3}$ and $\mathrm{KCl}$ respectively.

Whole plant samples consisting of the entire aboveground portions of the plant were taken at 8 weeks when plants were 20 to $25 \mathrm{~cm}$ in height, at 10 weeks when plants were at the early bloom stage and very little tuber development had occurred, and at 13 weeks when plants were well past the bloom stage. Plant slant samples were dried, weighed, ground, and dry-ashed at $500^{\circ} \mathrm{C}$. The residue was dissolved in $\mathrm{HCl}$ and analyzed for $\mathrm{Ca}, \mathrm{Mg}, \mathrm{P}, \mathrm{K}, \mathrm{Mn}$ and $\mathrm{Zn}$. The cations were analyzed by atomic absorption spectrophotometer expect for $\mathrm{K}$ which was analyzed by flame emission, $\mathrm{P}$ was determined colorimetrically (Murphy and Riley, 1962).

Tubers were harvested mechanically from two rows in each plots 112 days after planting, were graded, and were weighed. Tubers were graded into U.S. Grade b tubers 38 to $48 \mathrm{~mm}$ in diam. and U.S. Grade a tubers. The latter were further separated into the following four size fractions; A1, 4.8 to $6.4 \mathrm{~cm}$; $\mathrm{A}_{2}, 6.4$ to $7.6 \mathrm{~cm}$; A 3 , 7.6 to $9.5 \mathrm{~cm}$, and $A 4,>9.5 \mathrm{~cm}$. Soil from the harvested rows, which should have been mixed with any residual fertilizer by the harvester, was sampled immediately

After harvesting was done, the beds were plowed and sown to a cover crop of forage sorghum SSorghum bicolor (L. Moench). The sorghum was cut once in the summer and again in the fall and the residues were plowed back into the soil. The soil was again bedded for Jerusalem artichoke, and soil samples were taken from each plot on the first of March.

\section{The year of 2011}

Fuseau Jerusalem was seeded to all plots at the low $\mathrm{P}$ site on 10 March. The high $\mathrm{P}$ site was not included in the $\mathrm{P}$ study this year. Diammonium phosphate and (APP) were each banded at the rate of $23.52 \mathrm{~kg}$ P/Fed. to all plots except control. Nitrogen, Potssium, and the fritted micronutrient material were banded with $\mathrm{P}$ at the rates used in 2010. Side dressing of $\mathrm{N}$ and $\mathrm{K}$ was made 35 days after planting at rates of 23.52 and 19.32 $\mathrm{kg} / \mathrm{Fed}$, respectively. after harvesting tubers. 
Whole plant samples were taken from each plot 7 weeks after planting when plants were at the early bloom stage and after 10 weeks when plants were well past the bloom stage.

Tubers were harvested mechanically from one row in each plot 97 days after planting and then were graded and weighed. Soil samples were taken from the harvest row immediately after harvesting tubers. The soil was plowed, planted to forage sorghum, and the sorghum residue plowed into the soil. The land was rebidded for Jerusalem artichoke in summer, and soil samples were taken from each plot in March 2012.

\section{The year of 2012}

The variety Fuseau Jerusalem artichoke was seeded to each plot at the low P site on March. Diammonium phosphate and (APP) again were banded at the rate of $23.52 \mathrm{~kg} \mathrm{P} / \mathrm{Fed}$. to all plots expect the control plots. Fuseau Jerusalem artichoke were seeded to all plots at the high P site and (DAP) and (APP) applied at the rates used in 2010. Nitrogen, $K$, and the fritted micronutrients were banded with $\mathrm{P}$ at planting at the same rates used in previous years. Nitrogen and $\mathrm{K}$ were side dressed 35 days after planting at rates of 23.52 and $19.32 \mathrm{~kg} /$ Fed. respectively.

Whole plants samples were taken 10 weeks after planting, dried, ground, and analyzed as in previous years. Tubers were mechanically harvested 108 days after planting and then were graded and weighed. Soil samples were taken from each harvest row immediately after harvesting tubers. All soil samples were air-dried, sieved through a 10- mesh screen, and extracted for 5 min with $0.05 \quad \mathrm{~N} \mathrm{HCl}+0.025 \quad \mathrm{~N} \mathrm{H}_{2} \mathrm{SO}_{4}$ using a soil solution ratio of 1:4. Filtrates were analyzed for $\mathrm{P}$ as described earlier.

Fumigation of the soil was done each year prior to planting using the nematicide Telone II knifed into the row. The two sites were both irrigated and drained through porous tile spaced $18-\mathrm{cm}$ apart and $61-\mathrm{cm}$ deep. The water table was maintained $20-\mathrm{cm}$ below the alleys between the rows during the entire season.

Differences due to source of $\mathrm{P}$ were evaluated statistically using the method of orthogonal comparisons as described by Snedecor and Cochran (1967).

\section{RESULTS AND DISCUSSION}

\section{Plant Data in the year of 2010}

There was no significant interaction between lime and $\mathrm{P}$ treatments for any variable at either site. Therefore, only main effects of $\mathrm{P}$ source are presented. Source of $\mathrm{P}$ had significant effects on tissue element concentrations in tops of Jerusalem artichoke at the low $\mathrm{P}$ site at all three samplings. Table (2) gives tissue data for the early bloom stage only. Tissue $\mathrm{P}$ concentrations were lower in tops of plants fertilized with (APP) at all three sampling dates although differences at the first sampling were not quite significant. Present $\mathrm{P}$ in tops increased with the rate of applied $\mathrm{P}$ for both sources. However, (DAP) at the $23.52 \mathrm{kgP} / \mathrm{Fed}$. rate resulted in slightly higher P levels at early bloom than (APP) did at the $70.56 \mathrm{kgP} /$ Fed. rate.

Tissue concentrations of $\mathrm{Ca}, \mathrm{Mg}, \mathrm{Mn}$, and $\mathrm{Zn}$ were higher with (APP) at the low $\mathrm{P}$ site at all three samplings. Top dry weights (TDW) were greater with (APP) at the first sampling, less at the second, but not affected by source at the third. By the third sampling all plants had lower (TDW) and percent $P$ than at early bloom. Based on tissue concentrations and (TDW), plants fertilized with (APP) generally took up more $\mathrm{Ca}$, $\mathrm{Mg}, \mathrm{Mn}$, and $\mathrm{Zn}$ and less $\mathrm{P}$ than those fertilized with (DAP).

Total tuber yields averaged $12 \%$ lower with (APP) than (DAP) (Table 3). The primary effect of $P$ source on marketable tuber was a reduction in yield of the smallersized tubers with (APP), yield of Grade B and A1 tubers averaged 13 and $10 \%$ lower, respectively. However, yield differences of Grade A tubers as a whole due to $\mathrm{P}$ source were not quite significant .With both sources, marketable tubers averaged $87 \%$ of the total weight of tubers harvested.

Table (4) gives tissue data for plants at early bloom at the high $\mathrm{P}$ site. Tissue $\mathrm{Ca}$ and $\mathrm{Mg}$ were significantly higher with (APP) at the first two samplings. Source of $\mathrm{P}$ had no effect on tissue $\mathrm{P}$ except at the third sampling, where (APP) resulted in lower percent $\mathrm{P}$. In addition, $\mathrm{P}$ source had no effect on tuber yields (Table 5), (TDW), tissue $\mathrm{Zn}$, or $\mathrm{Mn}$ at any sampling.

\section{Plant Data in the year of 2011}

Tissue $\mathrm{P}$ concentrations were significantly lower with APP at both early bloom (Table 2) and at the later sampling. Because of the high availability of $\mathrm{P}$ applied in 2010, a significant amount of P needed by the second crop could have come from residual $\mathrm{P}$, particularly where the higher $P$ rates had been applied in 2010 .

Tissue concentrations of $\mathrm{Ca}, \mathrm{Mn}$, and $\mathrm{Zn}$ were significantly higher with (APP) at both samplings. Tissue $\mathrm{Mg}$ was higher with ( APP) at early bloom but the difference was not significant. Tuber yields and (TDW) were not affected by P source (Table 3).

The only significant interaction between lime and $\mathrm{P}$ treatments occurred at the early bloom stage for tissue $\mathrm{Zn}$ concentration. 


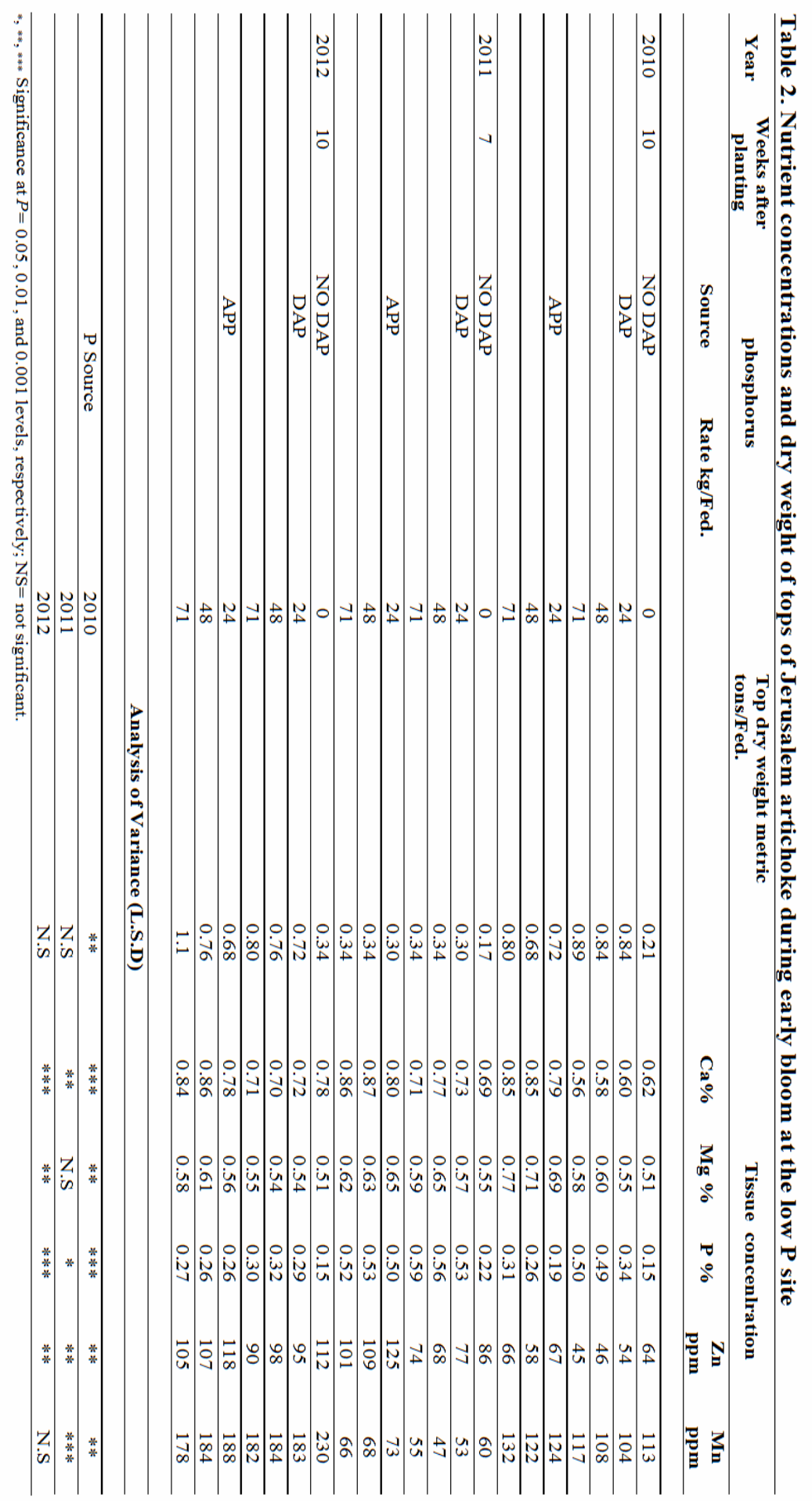


Table 3. Tuber yields of Jerusalem artichoke by grade and size at the low $P$ site

\begin{tabular}{|c|c|c|c|c|c|c|c|c|}
\hline \multirow[t]{2}{*}{ Year } & \multicolumn{2}{|c|}{ Phosphorus } & \multicolumn{3}{|c|}{$\begin{array}{c}\text { Size fraction } \\
\text { (metric tons/ fed.) }\end{array}$} & \multicolumn{2}{|c|}{$\begin{array}{c}\mu \text { Grade } \\
\text { (metric tons/fed.) }\end{array}$} & \multirow[t]{2}{*}{$\begin{array}{c}\text { Total yield } \\
\text { (metric tons/fed.) }\end{array}$} \\
\hline & Source & Rate & A1 & A2 & A3 & $\mathbf{A}$ & B & \\
\hline \multirow[t]{7}{*}{2010} & NO $P$ & 0 & 1.9 & 0.3 & 0.04 & 2.27 & 4.62 & 3.07 \\
\hline & DAP & 24 & 3.8 & 2.1 & 0.67 & 6.55 & 0.80 & 8.36 \\
\hline & & 48 & 4.4 & 1.6 & 0.46 & 6.55 & 0.84 & 8.57 \\
\hline & & 71 & 4.3 & 1.4 & 0.42 & 6.13 & 1.01 & 8.36 \\
\hline & APP & 24 & 3.7 & 1.7 & 0.46 & 5.88 & 0.71 & 7.31 \\
\hline & & 48 & 3.6 & 1.7 & 0.42 & 5.71 & 0.80 & 7.73 \\
\hline & & 71 & 3.9 & 1.5 & 0.42 & 5.75 & 0.80 & 7.48 \\
\hline \multirow[t]{7}{*}{2011} & NO $\mathrm{P}$ & 0 & 4.9 & 0.90 & 0.04 & 5.88 & 1.55 & 7.6 \\
\hline & DAP & 24 & 7.4 & 3.9 & 0.67 & 12.01 & 2.23 & 14.95 \\
\hline & & 48 & 7.0 & 3.8 & 0.88 & 11.59 & 2.14 & 14.53 \\
\hline & & 71 & 7.4 & 3.7 & 1.01 & 12.22 & 2.10 & 15.25 \\
\hline & APP & 24 & 6.9 & 4.2 & 0.80 & 11.97 & 1.89 & 14.87 \\
\hline & & 48 & 7.6 & 4.3 & 0.92 & 12.85 & 1.97 & 16.00 \\
\hline & & 71 & 7.5 & 4.2 & 0.84 & 12.60 & 2.06 & 15.71 \\
\hline \multirow[t]{12}{*}{2012} & NO $P$ & & & & & & & \\
\hline & DAP & 0 & 3.9 & 2.8 & 0.17 & 5.46 & 1.55 & 6.97 \\
\hline & & 24 & 6.3 & 4.2 & 1.10 & 11.59 & 1.85 & 14.07 \\
\hline & & 48 & 6.4 & 4.1 & 0.80 & 11.26 & 2.02 & 13.99 \\
\hline & & 71 & 6.6 & 4.3 & 1.18 & 12.10 & 1.89 & 14.74 \\
\hline & APP & 24 & 6.1 & 3.5 & 0.76 & 10.33 & 1.68 & 12.94 \\
\hline & & 48 & 6.5 & 3.7 & 0.71 & 10.88 & 2.01 & 13.73 \\
\hline & & 71 & 6.7 & 4.2 & 0.88 & 11.80 & 1.93 & 14.41 \\
\hline & & \multicolumn{7}{|c|}{ Analysis of Variance (L.S.D) } \\
\hline & P Source & 2010 & $*$ & N.S & N.S & N.S & $*$ & $* *$ \\
\hline & & 2011 & N.S & N.S & N.S & N.S & N.S & N.S \\
\hline & & 2010 & N.S & $*$ & $*$ & $*$ & N.S & N.S \\
\hline
\end{tabular}

*,** Significance at $P=0.05$ and 0.01 levels, respectively; $N S=$ not significant.

Tissue $\mathrm{Zn}$ decreased linearly with increasing rates of lime for both sources. Except for the highest lime rates, tissue $\mathrm{Zn}$ was significantly higher with(APP) than (DAP).

\section{Plant Data in the year of 2012}

At the low P site, (APP) again resulted in lower tissue concentration of $\mathrm{P}$ and higher tissue concentrations of $\mathrm{Ca}, \mathrm{Mg}$, and $\mathrm{Zn}$ (Table 2). Tissue $\mathrm{Mn}$ content was not affected by $\mathrm{P}$ source. Yield of Grade A tubers was significantly lower with (APP) than that of (DAP).The primary effect of $\mathrm{P}$ source was reduced yield of the larger sizes of Grade A tubers (Table 3). The lower yield of marketable tubers with (APP) was offset by greater quantity of cull Jerusalem artichoke in this treatment, marking total tuber yields similar with the two P sources.

At the high $\mathrm{P}$ site, tissue $\mathrm{P}$ content was lower and tissue $\mathrm{Zn}$ content higher was in case of (APP) (Table 4). Source of P had no effect on (TDW) or tuber yields (Table5).

\section{The Soil Data}

Extractable $\mathrm{P}$ at the low $\mathrm{P}$ site was only $6 \mathrm{ppm}$ initially, and tuber yields increased an average of $260 \%$ with the application of $23.52 \mathrm{~kg} \mathrm{P} / \mathrm{Fed}$. in 2010 (Table 3). 


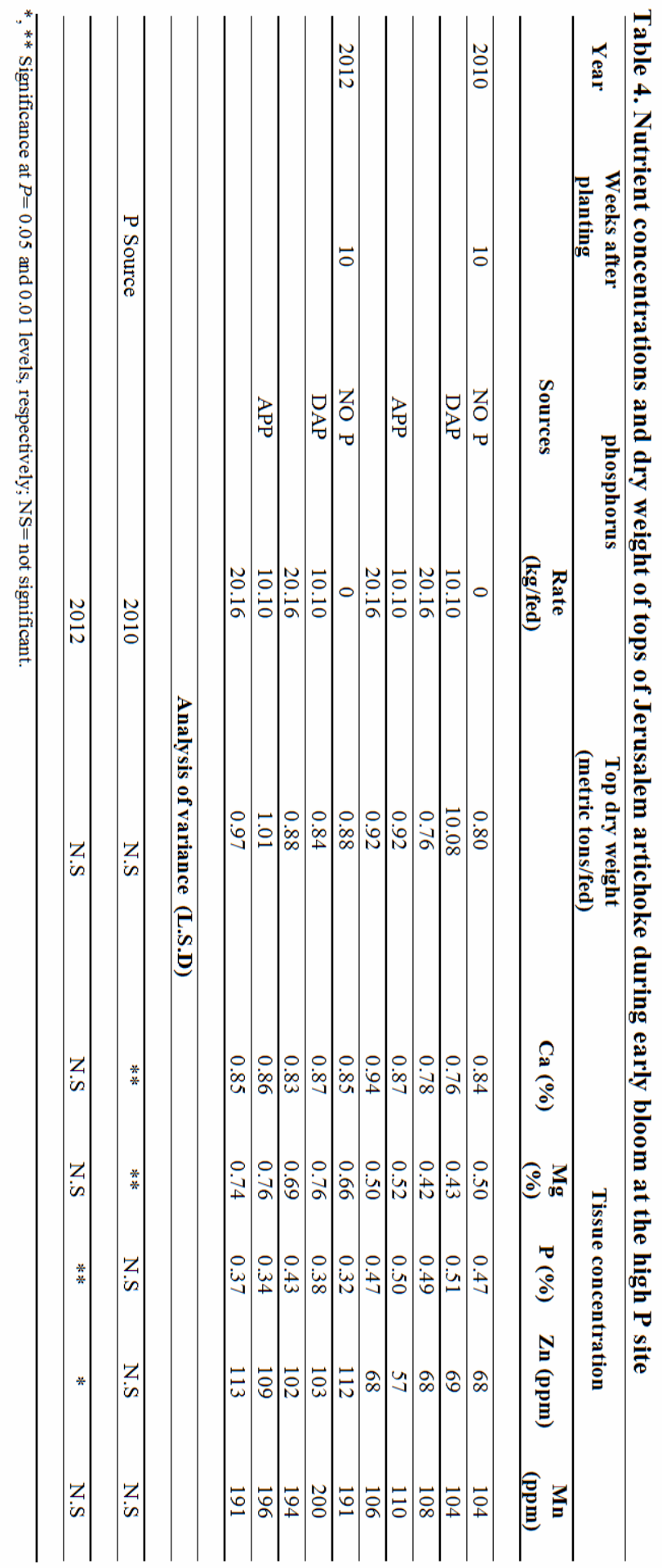


No further increase in yield was obtained with either $\mathrm{P}$ source at the higher rates. Post harvest soil samples in 2010 were significantly higher in extractable $\mathrm{P}$ with (APP) (Table 6). However, differences were not observed prior to planting or in post harvest soil sample in 2011. As a result of (APP) applications, significantly higher extractable-P levels were again observed in post harvest soil samples in 2012.

All post harvest soil samples were taken from the row where any residual fertilizer in the bands should have been well mixed with the soil. The higher levels of extractable P with (APP) could have resulted from the lower uptake of $\mathrm{P}$ from this treatment and / or the formation of fertilizer reaction products that were more soluble in the double-acid extractant. Although the fertilizer reaction products of (OP) and polyphosphate in soils have been studied (Savant and Racz, 1973; Lindsay et al., 1962; Philen and Lehr, 1967, Fatma et a.l, 2013), no information is available concerning their solubilities in the double-acid extracting solution.

No effects of $\mathrm{P}$ source on extractable soil $\mathrm{P}$ were observed at the high P site in either 2010 or 2012. Extractable P averaged 293 ppm during the study and was affected more by lime than that by P treatments.

Response of Jerusalem artichoke to (APP) or (DAP) was evaluated over a wide range of extractable soil $\mathrm{P}$ levels. At the low P site in 2010, extractable P was 6 ppm in all plots at planting, and ( APP) resulted in lower tissue $\mathrm{P}$ concentrations than (DAP) at each sampling. Yields of marketable tuber also were significantly lower with (APP). Because of the low levels of available soil $P$ at this site in 2010, the fertilizers were the major source of $\mathrm{P}$ for the crop. Under the conditions of this experiment, (APP) apparently could not provide adequate $\mathrm{P}$ for maximum yields. In 2011, extractable $\mathrm{P}$ ranged from 13 to $36 \mathrm{ppm}$ on plots receiving fertilizer $\mathrm{P}$. Tissue $\mathrm{P}$ concentration was again lower both samplings with (APP), but P source did not affect tuber yields. These results indicated that as available soil $\mathrm{P}$ increases, differences in tuber yields between (APP) and (DAP) will become insignificant even though tissue analyses may continue to show superiority of (DAP) in supplying $\mathrm{P}$ ranged from 21 to $37 \mathrm{ppm}$ on plots receiving fertilizer $\mathrm{P}$ at the low $\mathrm{P}$ site, both tissue $\mathrm{P}$ and yield of Grade A tubers were less with (APP). At the high $\mathrm{P}$ site, however tissue $\mathrm{P}$ was found with (APP), but $\mathrm{P}$ source did not affect either (TDW) or tuber yield either year.

The observation of Jerusalem artichoke were much more responsive to fertilizer $\mathrm{P}$ in 2012 with yield increases of 4-2 metric tons/Fed. occurring at the same extractable-P levels where no yield response to applied $\mathrm{P}$ was observed in 2011. At all extractable- P levels which occurred at the low P site in 2012, the crop was unable to obtain adequate $P$ from the soil for optimum yield. Thus, the increased dependence on fertilizer $\mathrm{P}$ at all soil $\mathrm{P}$ levels at this site probably explains why tuber yields were affected by $\mathrm{P}$ source in 2012 but not in 2011 Ahmed and Habel (2013) and EL-Sayed(2013).

A striking effect of $\mathrm{P}$ source in this study was higher concentrations of $\mathrm{Ca}$ and, to a lesser extent, $\mathrm{Mg}$, in the tops with (APP). Tissue Ca was markedly higher with (APP) at every sampling at the low $\mathrm{P}$ site. This effect of $\mathrm{P}$ source on tissue $\mathrm{Ca}$ was little affected by lime rates. Extractable soil $\mathrm{Ca}$ at this site ranged from $121 \mathrm{ppm}$ with no lime to $>800 \mathrm{ppm}$ at high lime rate. Exchangeable $\mathrm{Ca}$ increased from 0.5 to $>2.0 \mathrm{meq} / 100 \mathrm{~g}$ at these same lime rates. Increasing the level of soil $\mathrm{Ca}$ over these ranges did little to eliminate the effect of $\mathrm{P}$ source on tissue $\mathrm{Ca}$. In growth chamber experiments, Bennett and Fred Adams (1970) found that high rates of (DAP) mixed with a soil reduced exchangeable $\mathrm{Ca}$ and resulted in $\mathrm{Ca}$ deficiency symptoms in sudan grass (Sorghum sudanesis). The decrease in available Ca was attributed to precipitation of Ca phosphates. In the study reported here, $\mathrm{P}$ was banded and precipitation of $\mathrm{Ca}$ phosphates around the (DAP) granules could have reduced $\mathrm{Ca}$ availability in the fertilizer band. However, since availability of $\mathrm{Ca}$ in the remaining soil volume would have remained high, it seems unlikely that precipitation of $\mathrm{Ca}$ phosphates can explain the lower uptake of Ca with (DAP).

Application of (APP) resulted increased tissue concentrations of $\mathrm{Mn}$ and $\mathrm{Zn}$ in tops of Jerusalem artichoke. Rehm et al. (1980) found that Zn uptake by 3-week- old corn plants was higher when $\mathrm{Zn}$ was banded with fertilizer containing( PP) than (OP). These differences disappeared at the latter growth stages apparently because of (PP) hydrolysis. Hossner and Richards (1967) found Mn uptake by soybeans \{Glycine $\max (\mathrm{L})$ Merr.\} was higher with (APP) than (DAP). The data suggested that the availability of fertilizer $\mathrm{Zn}$ and $\mathrm{Mn}$ to Jerusalem artichoke is greater when banded with (APP) than when banded with (DAP).

The fact that the (APP) used in this study was liquid while the (DAP) was granular should have little bearing on the interpretation of the data. Lath well et al. (1960) compared liquid and granular formulations of several water-soluble $\mathrm{P}$ sources for supplying $\mathrm{P}$ to corn and small grains in New York, Iowa, and Several South eastern states.

They found that responses to the liquid forms on Pdeficient soils were similar to those obtained with (CSP) .In addition, response to $\mathrm{P}$ was similar when (APP) was applied in either liquid or granular form. 
Table 5. Tuber yields of Jerusalem artichoke by grade and size at the high $P$ site.

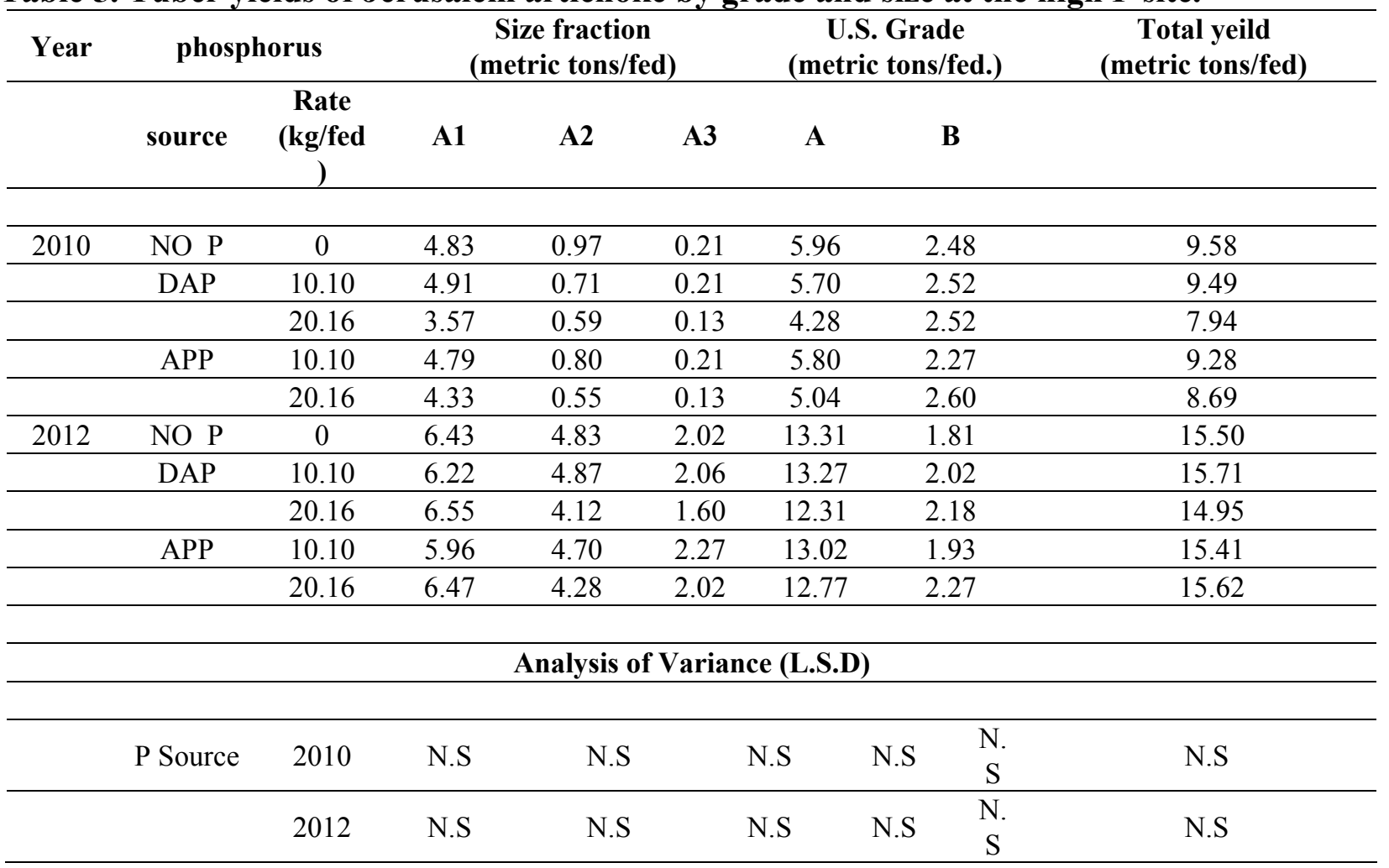

Table 6. Extractable phosphorus levels in soil samples from the low $P$ site

\begin{tabular}{|c|c|c|c|c|c|c|c|}
\hline \multicolumn{2}{|c|}{ Phosphorus } & \multicolumn{6}{|c|}{ Sampling dates } \\
\hline \multirow[t]{2}{*}{ Source } & \multirow[t]{2}{*}{ Rate } & \multicolumn{2}{|c|}{$2010(\mathrm{ppm})$} & \multicolumn{2}{|c|}{2011 (ppm) } & \multicolumn{2}{|c|}{2012 (ppm) } \\
\hline & & Jan & May & Dec & May & Jan & May \\
\hline NO $\mathrm{P}$ & 0 & 6 & 6 & 5 & 9 & 9 & 14 \\
\hline \multirow[t]{3}{*}{ DAP } & 24 & 6 & 18 & 13 & 28 & 21 & 27 \\
\hline & 48 & 7 & 25 & 25 & 37 & 29 & 33 \\
\hline & 71 & 7 & 33 & 36 & 47 & 37 & 42 \\
\hline \multirow[t]{3}{*}{ APP } & 24 & 8 & 21 & 12 & 28 & 21 & 49 \\
\hline & 48 & 6 & 32 & 22 & 42 & 30 & 51 \\
\hline & 71 & 6 & 43 & 25 & 47 & 34 & 63 \\
\hline \multicolumn{8}{|c|}{ Analysis of Variance (L.S.D) } \\
\hline P Source & & N.S & $* *$ & N.S & N.S & N.S & $* * *$ \\
\hline
\end{tabular}

$* *, * * *$ Significance at $\mathrm{P}=0.01$ and 0.001 levels, respectively; $\mathrm{NS}=$ not significant.

A possible exception to the authors' above conclusions might be when applying $\mathrm{P}$ to high fixing soils, where the greater initial soil contact by the liquid might be a factor. However, the placid sand is typical of the Flatwoods soils of Alexandria, and these soils fix very little P. phosphorus has been shown to leach from the surface horizons of these soils due to the low levels of reactive $\mathrm{Fe}$ and $\mathrm{Al}$ (Blue, 1970; Chaiwanakupt and Robertson ,1976; Ahmed and Habel, 2013; El-Sayed $(1996,2002,2003,2005,2013)$.
Although the amount of $\mathrm{P}$ applied in these experiments was the both sources, the amount of $\mathrm{N}$ in two sources varied with their respective N/P ratios. Differences in the amount of $\mathrm{N}$ applied in the $\mathrm{P}$ sources were eliminated by banding sufficient quantities of $\mathrm{NH}_{4} \mathrm{NO}_{3}$ to bring the total $\mathrm{N}$ applied up to 63.42 $\mathrm{kg} / \mathrm{Fed}$. However, because of the sources of $\mathrm{N}$ used, there were differences in the $\mathrm{NH}_{4}-\mathrm{N} / \mathrm{NO}_{3}-\mathrm{N}$ ratios in the fertilizer at planting. It is possible that some of the 
differences in response to $\mathrm{P}$ in this study could have resulted from the different $\mathrm{NH}_{4}-\mathrm{N} / \mathrm{NO}_{3}-\mathrm{N}$ ratios.

Volk and Gammon (1952) recommended that onethird and one-fifth of the $\mathrm{N}$ be from nitrate sources on new land and old land, respectively, to prevent nutritional leaf roll in Jerusalem artichoke. Except for the 47.04 and $70.56 \mathrm{~kg} \mathrm{P} / \mathrm{Fed}$. treatment in 2010, all fertilizer treatments met these recommendations. No nutritional leaf roll was observed at any time in this study. Other disorders have been reported where high rates of (DAP) were banded on potatoes \{Meisinger et al., 1978\}.

These disorders were attributed to ammonia and/or nitrite toxicities produced by the initially alkaline reaction of (DAP) in the soil. Toxicities from (DAP) were not a problem in this study since the highest yield were obtained with (DAP), and these plants showed none of the symptoms that have been attributed to use of high rates of (DAP).

A comparison of (APP) and (DAP) as sources of $P$ for summer-planted Jerusalem artichoke has shown that, under the conditions of these experiments, availability of fertilizer P was less with (APP) than with (DAP). Under conditions of low availability of soil $\mathrm{P}$, tuber yields were lower with( APP). At the higher levels of available soil $\mathrm{P}$, differences in tissue $\mathrm{P}$ were still measureable, but the Jerusalem artichoke apparently were able to obtain enough $\mathrm{P}$ from the soil so that differences in availability of fertilizer P had little effect on tuber yield. Application of (APP) to Jerusalem artichoke in comparison to (DAP) can be expected in result in greater uptake of $\mathrm{Ca}, \mathrm{Mg}, \mathrm{Zn}$, and $\mathrm{Mn}$.

\section{ACKNOWLEDGMENTS}

The author wish to acknowledge grateful and thank Eng. Mohammed Said Abbas (Technoalex for Agriculture contracting at Alexandria) for valuable practically supported to this research .

\section{REFERENCES}

Ahmed. Y. Habel. 2013. Prediction soil bulk density and moisture constants using particle size distribution for selected Libyan calcareous soils. Alex. Sci. Exch. Jour. 34(1):63-70.

Bennett, A.C and Fred. Adams. 1970. Calcium deficiency and ammonia toxicity as separate causal factors of $\left(\mathrm{NH}_{4}\right)_{2}$ $\mathrm{HPO}_{4}$-injury to seedlings. Soil Sci. Soc. Am. proc. 34:255-259.

Blue, W.G. 1970. The effect of lime on retention of fertilizer phosphorus in leon fine said. Soil crop Sci. Soc. Fla. Proc. 30:141-150.

Chaiwanakup, P and Robertson. 1976. Leaching of phosphate and selected cations from sandy soils as affected by lime. Agron. J.68:507-511.
Engelstad, O.P and Allen, S.E. 1971. Ammonium pyrophosphate and ammonium orthophosphate as phosphorus sources: effects of soil temperature, placement, and incubation. Soil Sci. Soc. Am. Proc35:1002-1004.

EL-Sayed, S.A.M. 1996. Responses of guar to applications of $\mathrm{P}$ and $\mathrm{Fe}$ in calcareous soils. J. Agric. Sci. Mansoura Univ., 21(7):2709-2719.

EL-Sayed, S.A.M. 2002. Relationship between ammonium thiosulfate (ATS) and inhibition of nitrification or urea hydrolysis in soil. Alex. Sci. Exch. Jour . 23(3):243-254.

EL-Sayed, S. A. M. 2003. Effect of EDDHA amendment to soil on P Solubility and availability by mycorrhizal guar plant. Alex. Sci. Exch. Jour. 24(1): 1-18.

EL-Sayed, S. A. M. 2005. Inoculation of non legumes by phosphate solubilizing microorganism. Alex. Sci. Exch. Jour. 26(3): 255-264.

EL-Sayed,S.A.M.2013.Relationship between the amount of available $P$ and manure application by calcareous soils.Alex.Sci. Exch.Jour.34(4):353-359.

Fatma, K. Sherif ; EL-Attar, H.A and Hoda, A.A. 2013. Monitoring $\mathrm{P}$ efficiencies and corn yield by VAM and sulfur application in calcareous soils. Alex. Sci. Exch. Jour. 34(1): 44-54.

Hossner, L.R and Richards. 1968. The effect of phosphorus source on the movement and uptake of band-applied manganese. Soil Sci. Soc. Am. proc. 32:83-85.

Hughes. J. D. and Hashimoto. 1971. Triammonium pyrophosphate as a source of phosphorus for plants. Soil Sci. Soci. Amer.Proc. 35:643-647.

Lathwell, D. J; COPE, J. T. Jr and Webb, j. r. 1960. Liquid fertilizers as sources of phosphorus for field crops. Agron. J. 52:251-254.

Lindsay, W. L; Frazir, A. W and Stephenson. 1962. Identification of reaction products from phosphate fertilizers in soils. Soil Sci. Soc. Am. Proc. 2b:446-452.

Meisinger, J. J; Bouldin, D. Rand Jones, E. D. 1978. Potato yield reductions associated with certain fertilizer mixtures. Am. Potato. J -55:227-234.

Murphy, J and Riley, J. P. 1962. A modified single solution method for the determination of phosphate in natural waters. Anal. Chem. Acta. 27:31-36.

Philen, Jn. O. D and Lehr, J. R. 1967. Reactions of ammonium polyphosphates with soil minerals. Soil Sci. Soc. Amer. Proc. 31:196-199.

Rehm, G. W; Wiese, R. A and Hergen, G. W. 1980. Response of corn to zinc source and rate of zinc band applied with either orthophosphate or polyphosphate. Soil Sci. 129:3644.

Savant, N. K and Racz, G. J. 1973. Reaction products of applied pyrophosphates in some Manitoba Soils. Can. J. Soil. Sci. 53:111-117.

Snedecor, G. W and Cochran, W. G. 1967. Statistical methods. Iowa state unit press, Ames. 
Soil Survey Staff. 1998. Soil Taxonomy:A basis by system of soil classification for making and interpreting soil surveys .U.S.D.A.Handbook No.436,U.S.Government Printing Office, Washington,D.C.

Sutton, C. D; Gunary, D and Larsen, J. 1966. Pyrophosphate as a source of phosphorus for plants: \#. Hydrolysis and initial uptake by a barley crop. Soil Sci. 101:199-204.

Sutton, C. D and Larsen, S. 1964. Pyrophosphate as a source of phosphorus for plants. Soil Sci. 97:196-201.
U.S.D.A.(2011).Soil Survey Laboratory Information Manual.Rep.45,Version 2 .0.

Van Wazer, J. R. 1958. Phosphorus and its compounds. I. Chemistry. Wiley Interscience Publishers, Inc., New York.

Volk, G. M and Gammon, N. Jr. 1952. Effect of liming and fertilization on yield and the correction of nutritional leaf roll of Irish potatoes. Flag. Agric. Exp. Stn. Bull. No. 504.

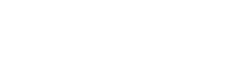

بولي فوسفات الأمونيوم، وأرثوؤسفات الأمونيوم كمصدر الفوسفور في نبت الطرطوفة

سعيد عبلس محمد اللسيد

دلت النتائج في الموق ع ذ ذو المحت ـوي المرنف عـم ن

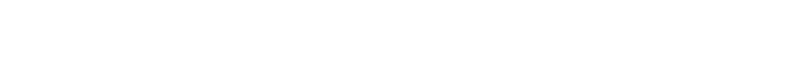

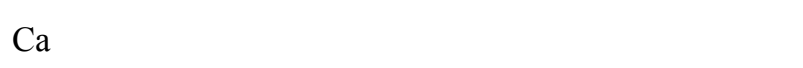

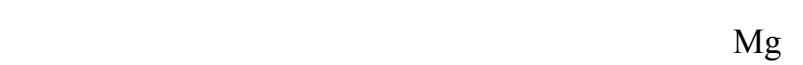

إلمتخدلهسماد (APP) كان منخفضاً في عنصر الفوسفور.

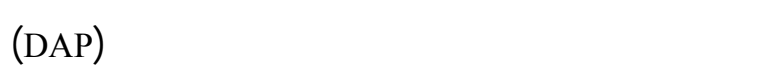

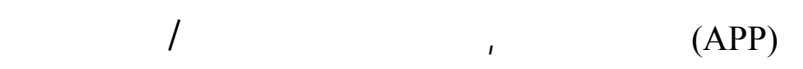

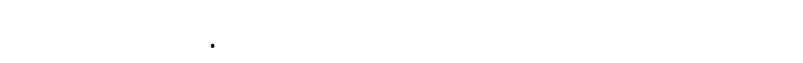

النتائج علي أن مستوي الأنسجة من الفوسفور كلن منخفضاً

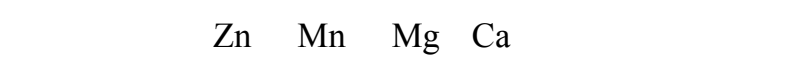

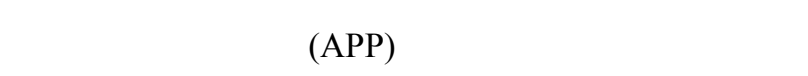

$$
\text { و }
$$

لوظظ أن محصول درنات نبلت الطرطوفة كان منخفضأ

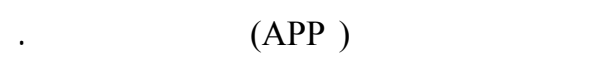

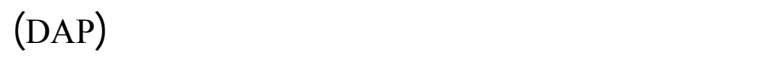

و) (APP) بمعدلات مررعة من الفوسفور وبنفس المعدلات

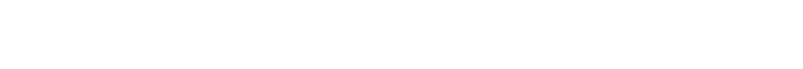
المحصول كان غير مؤثرأ عند أستخدله الفوسفور كمصدر

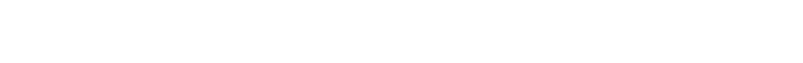

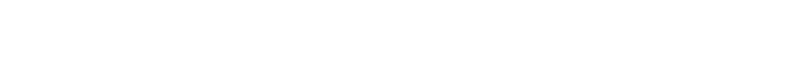
سماد (APP).
فذت تجربة حقلية في علم · · م المقارنة ت أثير داي

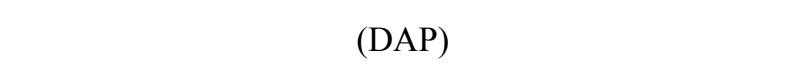

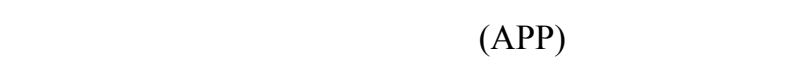
العناصر الغذائية اللطرطوفة.

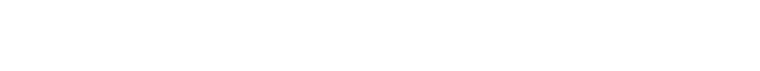

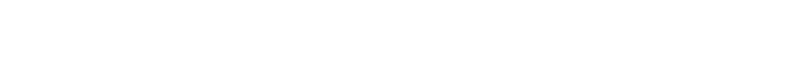

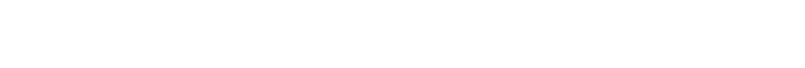

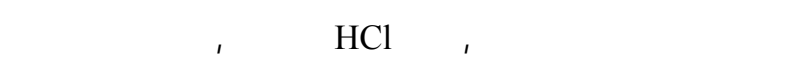

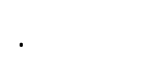

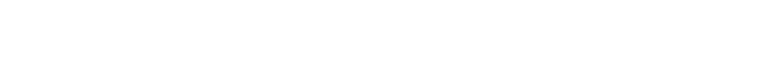

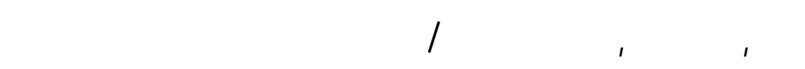
الفوسفور في الموقع الاول، وفي الموقع الثاني مم إض الفة

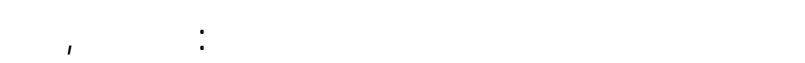

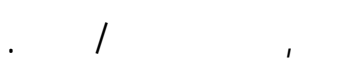

ولشارت النتائج إلي انه: - ف عي الموق ع ذو الم سستوي

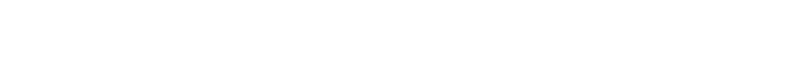
الطرطوفة وكذك تركيزمحتوي الفوس فور ف في أن عسجة

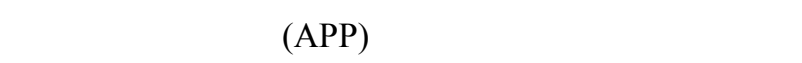

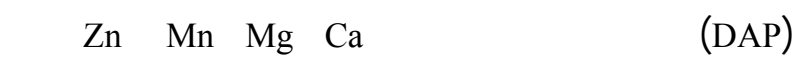

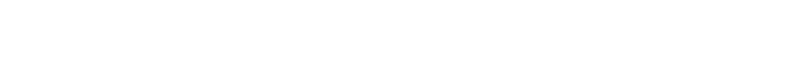
.(APP) 
عنها عند أستخدلم (DAP)، دلت النتائج ان تركيز الفوسفور

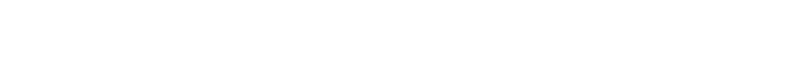
مقارنة بتركيز الفوسفور المستخلص من التربة.

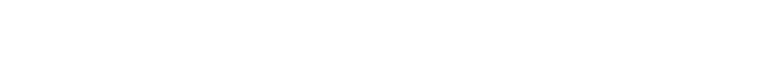

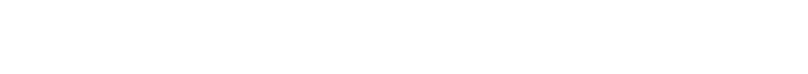

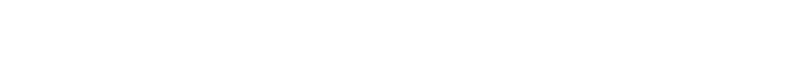

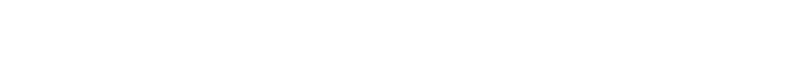
بها مستوي منغفض من الفوسفور المتيسر.

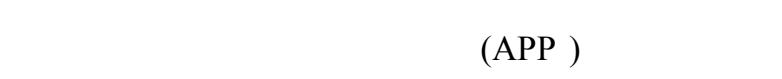

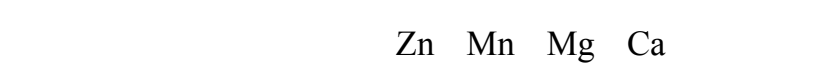
الطروطة.

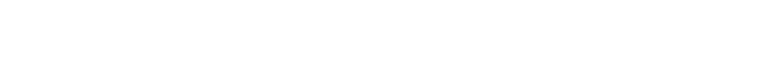

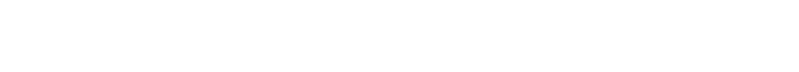

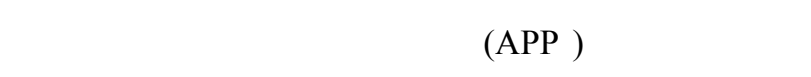
المستخلص يتناوص بمرور الوقت لكل منسمادي (APA) ) أوضحت النتائج خلال موسم النمو أنه لا توجد لختلاف لـ

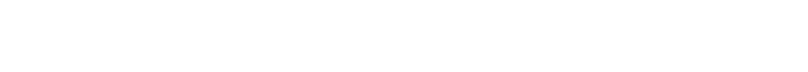
مصادر الأسمدة الفوسفاتية المستخمة.

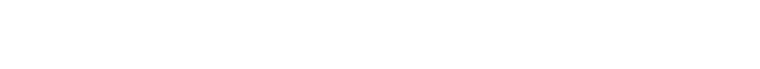

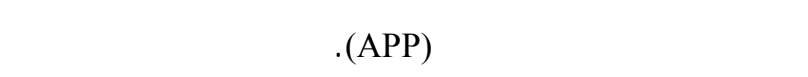

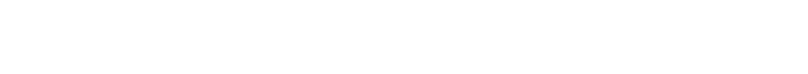
الطروفة في الصف كان منخفضاً عند أستخدلم (APP) 